\title{
Translocal space across migrant generations: the case of a Greek orthodox church in the UK
}

\author{
Kallis, Gina
}

http://hdl.handle.net/10026.1/12471

10.1002/psp.2206

Population, Space and Place

Wiley

All content in PEARL is protected by copyright law. Author manuscripts are made available in accordance with publisher policies. Please cite only the published version using the details provided on the item record or document. In the absence of an open licence (e.g. Creative Commons), permissions for further reuse of content should be sought from the publisher or author. 


\section{TRANSLOCAL SPACE ACROSS \\ MIGRANT GENERATIONS: THE CASE OF A GREEK ORTHODOX CHURCH IN THE UK}

Gina Kallis, Richard Yarwood and Naomi Tyrrell

School of Geography, Earth and Environmental Sciences

Plymouth University

Drake Circus

Plymouth

Devon

UK

PL4 8AA

Accepted for publication in Population, Space and Place

$9^{\text {th }}$ August 2018

\section{KEYWORDS}

Translocality; intergenerationality; religon; Greek-Cypriot; UK 


\section{ABSTRACT}

This paper examines the changing importance of translocal space to three generations of Greek-Cypriot migrants in the UK. Focusing on a Greek Orthodox Church, the paper draws upon participant observation and interviews to examine how translocal spaces is given meaning by migrants and, in turn, how the meaning and use of translocal spaces is re-negotiated and altered by later generations. Based on this evidence, we argue that translocal space strengthens community ties and offers a way of performing particular ideas of identity and culture. It provides social and cultural links to distant people and places through shared religious practices. Intergenerational perspectives allows us to understand how translocal places are reproduced, challenged and changed by successive generations. In doing so, the paper advances our understanding of translocality, the different ways that translocal space is used by migrant generations and the changing significance of places of worship to migrant identities.

\section{INTRODUCTION}

Local places and everyday routines are important in the lives of migrants and their families (Ho \& Hatfield, 2011). While some are hyper-mobile (Leung, 2004:9), most migrants' lives are locally anchored and concrete (Levitt \& Waters, 2006). Migrant identities are often more closely related to localities within nations than nations themselves. However, the significance of local places in transnational networks changes as successive generations imagine or use them in different ways (Kelly \& Lusis, 2006; Levitt \& Waters, 2006). In this paper we contribute to this emerging work by examining how three generations have engaged with the space of a church established by GreekCypriot migrants in a British city. It has two main aims. First, it examines the changing significance of translocal space to successive generations of migrants. Particular 
attention is given to the ways the different translocal engagements alter the significance of particular spaces and, in turn, how these re-imaginations influence the subsequent use of particular places. Second, and more specifically, it scrutinises the significance of the church and religious practice in the formation and maintenance of translocal space. Before introducing the case study, the paper continues by demonstrating the significance of translocality to migration studies.

\section{TRANSLOCALITY, INTERGENERATIONALITY AND PLACES OF WORSHIP}

\section{From transnationalism to tranlocalism}

Transnational interactions are important to many migrants' lives (Levitt \& Waters, 2006) but the intensity, significance and nature of these connections varies between generations (Guarnizo, 2000). Thus, economic connections are initially important for first-generation migrants, commonly in the form of sending remittances home (Yang, 2011), while religious, political, cultural and social practices often become more important to subsequent generations (Christou, 2006; Dwyer, 2002; Hopkins, 2006). It is increasingly recognised that these activities are 'grounded' in specific sites, such as shops, homes, schools or neighbourhoods (Brickell \& Datta, 2011, Kong 1999), that are enrolled into transnational networks that shape migrants' identities and strengthen international linkages (Ferbrache \& Yarwood, 2014; Smith, 2001).

The idea of 'translocality' (Appadurai, 1996) draws attention to the importance of a locality 'within a network of spaces, places and scales where identities are negotiated and transformed' (Brickell \& Datta, 2011:5). The term captures 'the essence of mobility without losing sight of the importance of place and place-based associations' (Phillips \& Robinson, 2015:411) and recognises the significance of place within international networks (Brickell \& Datta, 2011:4).

Existing work has started to recognise the significance of translocal sites to migrant identities and practices (Greiner \& Sakdapolrak, 2013; Hall \& Datta, 2010) and identified how collective memory and nostalgia enable migrants to enact and experience collective belonging (Fortier, 2006; Leung 2004; Oakes \& Schein, 2006). Hatfield's (2011) revealed that the homes of Singaporean migrants allowed everyday social practices to occur that made cultural connections with distant places. In a similar thread, Datta (2011) explores how spaces of neighbourhood have been used by Polish migrants living in London to create a sense of belonging in order to maintain cultural links with Poland. Goulbourne et al. (2010) also found that language schools and churches represent a 
focal point for the transmission of cultural values and practices in many migrant communities.

This work, however, has largely been confined to second generation immigrants and little is known about the ways the third generation engage with these places. Research on third-generation migrants has focused on intergenerational language use (Alba et al., 2002 Kim \& Yoo, 2015; Papapavlou \& Pavlou, 2001) or economics (Hammarstedt, 2009), but there but there are very few studies that take into account the relationship of thirdgeneration migrants with translocal places, particularly in Britain (Parreñas, 2005; Zhou, 2009). Questions remain about whether or how translocal sites retain their significance to later generations, especially as the nature of transnational interactions changes over time (Guarnizo, 2000).

Studies using 'practice based' approaches to quantify transnational engagement have concluded that transnational engagement declines among second-generations (Kasinitz et al., 2006; Portes \& Rumbaut, 2001). Consequently local sites may lose their importance in transnational networks. Alternatively, work applying 'process approaches' (Wessendorf, 2013) has sought a more nuanced understandings of transnational lives by examining how they are co-produced through practices such as parenting and community engagement. Thus, Levitt (2009) argues that transnational attachments are not necessarily confined to the first-generation, as second-generation children are often raised in households that are regularly influenced by people, objects, and practices from their parent's home country. The homeland is ideologically referenced in daily routines by the first-generation, who use this backdrop to construct gender norms, ethnic identities and morals (Choudhry, 2010; Dwyer, 2002). These second-generation children are situated between competing 'generational, ideological and moral reference points, including those of their parents, their grandparents and their own real and imagined perspectives about their multiple homelands' (Levitt, 2009:1238). They may find themselves negotiating a variety of competing identities in their everyday lives as they attempt to please their parents while also fitting in with others of their age (Choudhry, 2010; Foner and Dreby 2011; Hopkins 2006; Knott \& Khokher, 1993). While this work has revealed some the ways in which transnational identity is negotiated between firstand second-generation migrants (Hopkins, 2006; Levitt, 2009; Levitt \& Waters, 2006), the role of translocal space in these dialogues is less clear. It might be speculated that the meaning and use of translocal spaces change as transnational identities are renegotiated. 
There is therefore a need to understand better how translocal spaces impact on the way intergenerational identities are negotiated, contested and re-imagined, especially beyond the second generation. Greiner \& Sakdapolrak (2013) advocate that an actororientated approach has the potential to reveal some of the complexities that help to shape translocal spaces, especially in regard to temporal dynamics and time-space interconnections. By focusing on the ways that individuals from different generations respond to and shape translocal spaces, it is possible to trace how the meanings, significance and interconnectness of translocal space change over time.

We now use places of worship to exemplify and explore these ideas.

\section{Places of worship}

Although Western society has generally become secularised (Taylor, 2007), there is evidence to suggest that religion still remains highly important for immigrant communities (Goulbourne et al., 2010). This is particularly the case for more recent immigrants who often become more observant of religious practices after they move, partly because places of worship offer a sense of belonging (Erhkamp \& Nagel 2012) through familiar practise and rituals (Tse, 2011, Goulbourne et al., 2010).

Places of worship play a particularly important role in the creation, maintenance and negotiation of transnational space. They not only represent particular values, identities and traditions but, as Ehrkamp and Nagel (2012) stress, are the places in which new forms of ethnic and migrant identities are contested, played out and imagined. Houses of worship 'serve to maintain spiritual (and financial) links with homelands, becoming hubs within transnational circuits of religious practice, material culture and leadership, all of which are tied to the multi-local reproduction of communal identities' (Ehrkamp and Nagel 2012:626). For example, the highly ritualised and repetitive acts of a Catholic mass help to cultivate a sense of belonging amongst London's Italian community (Bell, 1999; Fortier, 1999). Churches also play an important role in generating social capital and providing a range of personal and social services (Faist, 2000; Ley, 2008). In this way, they also act as places of citizenship, creating space for immigrants to engage politically, socially and culturally with wider society (Ehrkamp \& Nagel, 2012, Dwyer et al., 2015).

Yet there is a complex and shifting relationship between faith and migration: religious practices 'are not simply transplanted from homeland' (p.626) but undergo 
transformation and change in the context of particular places. Indeed, some churches have actively sought migrants in order to boost congregations, with the consequence that the style and format of worship has changed to accommodate them. The relationship between religious practice and migration cannot simply be 'read' but should be recognised as significant, complex and continually negotiated through personal and community practices. While religious practices and rituals transcend spatial scales (Greiner \& Sakdapolrak, 2013), it is also important to recognise that churches are also translocal spaces that are experienced and imagined subjectively by migrants (Conradson and McKay, 2007).

Ehrkamp and Nagal (2012) suggest that intergenerational differences impact on religious practice with important consequences. Thus, some younger generations may practice religion that attends to their social needs, rather than conforming to the traditional or cultural practices of their parents. Others may marry outside their ethno-religious communities, leading to changes in both attendance and religious practice, perhaps, for example, adopting more secular lifestyles or attending different churches. Changing religious practices have important implications for not only migrant identity but also the translocal space of the church itself. If the practice of religion diminishes or changes the church may cease to be a place that connects migrant communities to their countries of origin. In short, it becomes a local rather than a transnational space. There is a need, therefore, to examine the significance of the church to successive generations of migrants and, in turn, understand how this translocal space affects, and is affected by, these changes.

To begin doing this, we examine how a Greek Orthodox Church is used by three generations of Greek-Cypriot migrants living in Britain. As this section has suggested, churches exemplify some of the tensions between mobility and locality that characterise translocal space (after Greiner and Sakdapolrak 2013). One the one hand, churches have a physical, fixed presence that impacts on the urban landscape and provides a focal point for local communities and community practices. One the other hand, they are shaped by more-than-migratory flows, such as spiritual practices or symbolic ideas, that cross local and national boundaries. Furthermore, in adopting an actor-orientated approach, churches allow researchers to focus on the different ways in which individuals engage with, negotiate and transform local places in response to wider social and cultural norms. In this paper, we examine the ways in which translocal space is significant to understandings of migrants' lives and identities, even though this space is imagined and 
used in different ways between and within different generations. In particular, we take an intergenerational perspective to allow us to appreciate the ways in which translocal space can be reproduced, as well as challenged and contested, by successive generations. The following section provides a context for this work by introducing GreekCypriot migration in the UK.

\section{THE CASE OF GREEK-CYPRIOT MIGRANTS IN THE UK}

Cyprus has always been a country of emigration and, as a former UK colony, many Cypriots have migrated to the UK (Teerling, 2011). The bulk of this migration took place in the 1950s and 1960s (King et al., 2011; Teerling, 2011), with economic factors being the main motive (King et al., 2008). Estimates of the number of Cypriots living in the UK today vary greatly, however the National Federation of Cypriots in the UK, claims to represent more than 300,000 Britons of Cypriot ancestry ${ }^{1}$. The majorty of research focused on Greek-Cypriot communities in Britain has been limited to the first and secondgeneration and, in particular, those living in London (for an excpetion see Burrell, 2005).

Earlier work focused on those who migrated in the 1950s and 1960s and shows how kinship, family and village networks were utilised to facilitate migration and settlement in the UK (Anthias, 1992; Josephides, 1988). Many migrants placed extremely high value on family-life and family commitments (Constantinides, 1977). This was often highly gendered, with concepts of honour and shame being used to control women's lives and under-lying many aspects of their economic and social life (Anthias, 1992; Josephides, 1988). Intergenerational work, however, has suggested that these views are no longer as important to sucessive generations of Greek-Cypriot families. Instead, the use of language contributes to many second- and third-generation migrants identifying as Greek-Cypriot, rather than English/British (Charamlambous et al. 1988; Papapavlou and Pavlou, 2001). Work explored the experiences of second-generation Greek-Cypriot 'returnees' to Cyprus (King et al., 2008; King et al., 2011) confirms that a degree of 'Cypriotness' is maintained by returnees but often in altered, 'fresh or 'unconventional' (p.1089). This demonstartes a need to examine identity between and across generations and that the experiences of belonging 'cannot be captured within predefined ethnic, national or sociocultural boundaries' (Teerling 2011:1080).

In the following sections, we focus on a church as an example of significant translocal space. We employ an intergenerational approach that is inclusive of the third-generation

\footnotetext{
${ }^{1}$ This total includes those of both Turkish-Cypriot and Greek-Cypriot origin.
} 
as it has been neglected amongst this group of migrants in Britain. More broadly, the paper contributes to debates about intergenerational relations amongst migrant families and communities, and the importance of religious practices and socialisation amongst migrant communities.

\section{METHODOLOGY}

Our study is situated in a large provincial 'down-scale' city in England with a relatively low population of Greek-Cypriots. Cypriots first moved to the city in 1935, and between 1951 and 1991, the number rose steadily. Since then it has remained stable. According to the 2011 Census, there were 256 Cypriot-born individuals living in the city, but membership of the Greek Orthodox Church and Greek School suggest there are 400500 individuals of Greek-Cypriot descent living there.

The following discussion is based on findings from 48 qualitative interviews, as well as participant observations, undertaken in an ethnographic setting from June 2014 until October 2015. Qualitative interviews were conducted with members of three generations of Greek-Cypriot families. A statistical classification of 'generation' is used whereby the first-generation are those individuals born in Cyprus who moved to the UK, whilst their offspring who are born in the UK are the second-generation (Skrbiš et al., 2007). Following on from this, the children of the second-generation are referred to as the thirdgeneration. Those classed as the first-generation had all left Cyprus during adulthood or nearer the end of their teen years. There was a fairly even spread between second- and third-generation participants, however only seven first-generation participants took part in a formal interview. Members of this group were the least willing to participate, with several of them claiming they had migrated so long ago that their memories were vague (although there were several who were happy to answer a few questions informally). The sample also includes formal interviews with two English women who had married 'into' the families.

Adult participants were asked to recount their life stories and this yielded rich and detailed accounts of their pasts and presents (Lieblich et al., 1998), while the interviews with children (there were 15 in total) were more structured. All participants were given a choice as to whether the interview was conducted in Greek or English and for the small number who chose Greek, an interpreter was used. All participants were informed that all matters discussed during the interview would remain confidential, and that pseudonyms would be used so that their identity would remain anonymous. 
The interviews were supported by ethnographic observatoins carried out over a year. These involved regularly attending Sunday services, helping out with Greek School classes on Saturdays (held at the church) and attending other events organised by the two institutions, as well as visiting family homes for dinner/birthday parties on invitation. These occasions offered an insight into some of the social practices and interactions taking place among the local ethnic community, and provided a more in-depth understanding of the lived experiences of individuals.

\section{CREATING TRANSLOCAL SPACE}

The interviews revealed that religious practices were significant to the first-generation of migrants, particularly those linked to key events in the lifecycle such as birth, marriage and death. Initially many migrants attended local protestant churches but it became apparent to them that there was a spiritual and social need to follow Greek Orthodox practices. Thus, until the late 1960s, a Greek Orthodox priest would periodically visit from London to carry out baptisms in individuals' homes. These observances not only held spiritual significant but, when conducted in the context of the Greek Orthodoxy, also served to reproduce and enact ethnic identity. Later an Anglican church was rented on Sundays and when the English liturgy finished at 12 o'clock, an Orthodox priest would conduct the Greek liturgy. These ceremonies helped to create a, albeit temporary, translocal space that linked the church to a wider, transnational set of Orthodox practices shared by Greek-Cypriots. In this way, religious practices served to connect migrants with their homeland in Cyprus.

Yet, while these gatherings allowed migrants to practice key elements of their Orthodox faith, there was a desire to establish a more tangible Cypriot space in the town. Members of the first-generation recounted their communal struggle to obtain finances to establish their own church:

Later we decided to buy our own church. We looked at many places; we couldn't afford it, the prices were too high. This church, we were a bit lucky, so to speak. When we went to see it to purchase it, it was closed, deserted [...] We asked how much they wanted. We were three people. They told us that they wanted $£ 125,000$. We said that we cannot afford it, that we are poor! (Mid-eighties, firstgeneration male)

Given their perceived poverty, the church was significant financial investment. But, perhaps more than this, it was also a social investment in their new city. Rather than 
sending surplus money home, it was instead used to establish cultural and ethnic, rather than simply economic, connections with Cyrus (see also Dwyer 2002). One of the founding members stated:

we have the Greek nationality and if we hadn't had the church and the school we wouldn't belong anywhere. We would be a lost community ... Nobody would have known us, so to say, but now we have got our community even if it is small. (Anna, 81 years old, first-generation female)

The quote illustrates how, for some of the older participants, the church was particularly important in bringing members of the ethnic group together. Anna also emphasises how important it was for the community to have a physical marker of their presence within the urban environment. The community is not 'lost' but it is phsyically emplaced - the church provided a translocal space where members of the community could achieve a sense of ethno-cultural belonging as well as a clear sense of difference and identity.

The physical appearance of the church and the particular Orthodox ceremonies performed in it re-enforced these ideals. Figure 1 shows the distinctive appearance of the interior of the church, which is very different to other Christian churches in the UK, and the icons of saints that play a key part in many rituals, with members of the congregation bowing to and even kissing them as part of their expression of faith. The church provided a physical space where cultural and religious traditions and rituals could take place that were common to the first-generation's homeland. These practices helped to establish the church as a translocal place by providing a space to mobilise and affirm nationally collective ideas of religion (Faist, 2000).

An example of this is the celebration of Easter, which is seen by many as the most important event on the Greek Orthodox calendar. Celebrations begin on the Thursday evening before Good Friday when only women attend the church to decorate the Epitaph $^{2}$ with flowers (Figure A). This is followed on the Friday evening by a ritual lament known as the "Procession of the Epitáphios of Christ" which mourns the death of Christ on the cross and sees the believers carrying the Epitaph, first through the church, and then through the streets. Some first-generation individuals commented how, in Cyprus, the Epitaph would be carried through their villages, while in the UK, it was carried in a

${ }^{2}$ A symbolic coffin 
loop around the outside of the church and down the back lane. This highlights the desire to continue to perform such rituals, no matter the circumstances, and how they are adapted in the host country.

The midnight Service of the Resurrection then takes place on the Saturday evening. Each member of the congregation is given a candle and just after midnight, the priest's flame $^{3}$ was lit; this was then passed on from person to person. Traditionally, this is followed by traditional singing and chanting. While in Cyprus this would take place in overflowing churches and their courtyards, in the host city, this usually takes place in the space outside the church (weather-permitting). A second liturgy then took place during the day on Sunday, after which many families went on to have an Easter feast of Cypriot food in their homes. As the Easter celebrations show, the church's purpose goes beyond the spiritual; it offered a space where individuals can continue to practice the cultural and religious traditions of the homeland, helping them to feel a sense of home and belonging in the host society, as one first-generation interviewee stated:

We must strengthen these things. We must bring music, dance, give the Greek culture in our children. To speak only the language is not enough. The culture is very important. They must learn how we feel. Details?

Indeed, the significance of intergenerational and close familial relationships were commonly cited by participants as important elements of the Greek-Cypriot identity. It is important to understand that these were not just confined to the private spaces of the home but needed to be co-produced and confirmed in public spaces with other Cypriot families (Georgiou, 2001). In this case, the church provided a public space that allowed these intergenerational familial relationships to be manifested and celebrated publically through rituals such as baptisms and Easter but, significantly, through regular family attendance at church.

\section{CHANGING PRACTICES AND IDENTITY}

The church offered people a space where important versions of the Greek-Cypriot identity could be performed through religious practices, particularly for first-generation migrants. However, its significance was more ambiguous for later-generations, especially those of mixed ancestry. There was evidence that many invoked an 'ethnic choice' (Waters 1990) as to how and whether they participated in the church. For some,

\footnotetext{
${ }^{3}$ Symbolic of the light of the Resurrection
} 
participating in church activities and practices offered an ethnic identity that was perceived to be authentic and traditional (see Sullivan, 2012):

I'm British, you know, so I don't feel Cypriot at all because I don't speak the language so the only time I feel a little bit like that is when I go to church and I'm with my, with the guys and then I feel that I'm a Cypriot and that's the only sort of moments, just maybe one hour of the week, the rest of the time I'm British. (Chris, 83 years, second-generation male)

Thus, we can see how Chris performs a particular element of the Cypriot identity when he is with 'the guys' at church. This was witnessed regularly on Sundays after the church service when attendees went downstairs into the basement of the church for coffee and cake and Chris would always sit in one corner with some of the elderly men from Cyprus. For Chris, the times when he is with 'the guys' are when he is Cypriot and feels a strong sense of belonging within the Cypriot community (Bell, 1999). Interestingly, the church enabled second generational migrants to practice a Cypriot identity that had never been lived out in Cyprus. The space of the church is therefore significant as it provides a communal setting where collective affective belonging can be enacted and experienced by migrants with different experiences and backgrounds (Fortier, 2006; Leung, 2004).

Chris was not alone in this and several participants, of varying ages and gender, spoke of the importance of meeting and chatting with other members of the ethnic community at church - in particular speaking Greek. Language is commonly perceived as one of the markers of an 'authentic' ethnic identity (Papapavlou \& Pavlou, 2001; Sullivan, 2012), therefore speaking in Greek was a central part of the 'performance' of this. Significantly, the church offered the only space where this could be achieved by Chris, reflecting its translocal importance.

While members of the first-generation saw the language as an important element of the Greek-Cypriot identity, it was later-generations who were able to exert ethnic choice and to 'pick and choose' which aspects of their ethnic identity they emphasised and when (Waters, 1990). Hence later-generation migrants were able to practise a flexible form of ethnicity where the ethnic role was more voluntary than ascriptive; they could use the language when they were choosing to emphasise their Greek-Cypriot identity. The majority of participants who were parents recognised the importance of the church and school as spaces which promoted and reproduced ideas of ethnic identity: 
The reason why we have the Greek church, we have the Greek School here is because we want to sort of keep it - try and keep it alive in the Greek community for the kids as well [...] The reason why I send my [daughter] to [Greek] school is a couple of reasons really. It's for the community, so she gets to know all the Greek community and so that she doesn't forget that where her grandparents or one half of her grandparents have come from, so she needs to learn that history ... it's a good thing for them to know. (Deo, 48 years, second-generation male)

Like other members of the second-generation, Deo recognised the key role these translocal institutions played in the transmission of religious and cultural knowledge (especially the Greek language) and the maintenance of the ethnic identity. This is one reason why many parents and grandparents felt it was important for children to attend and, while the majority of the second-generation did not attend church every week, they did ensure that their children attended Greek School regularly on Saturdays. Attendance also contributes to the development of social and cultural capital as individuals are able to build ethnically-based social bonds within the Greek-Cypriot community (Kelly \& Lusis, 2006; Zhou, 2005).

Extremely high value was placed on the church as a translocal space by members of the first-generation, both in the way it acted as a physical marker of the ethnic group's presence in the city, as well as its role in promoting and maintaining the ethnic identity. The majority of first-generation migrants attended church every Sunday, but there appeared to be a decline in the regularity of church attendance among the second- and third-generations.

\section{CHANGE, TRANSGRESSION AND NEGOTIATION BETWEEN THE GENERATIONS}

As migrants became more established in the city, they also became less dependent on the church for services and friendship, and so second-generation migrants were less likely to attend for these reasons. There was also evidence that marriage outside the Greek-Cypriot community as well as other, non-secular pressures dulled the edge of attendance. Like Selena, a number of them preferred to 'make the most' of their Sunday, which was the only day of the week where the whole family could go out together and the need to spend 'quality time' with family members was used to justify their absence at church:

Mum and dad go regularly, I go sometimes ... the reason for that is that Philip [husband] works all week so he has Sunday off, I don't want to be like 'oh I'm gunna 
go' because by the time I leave from Greek Church it's one o'clock in the afternoon ${ }^{4}$, that's mostly the reason for it. I would go to things like, you know, Easter and if there's any nemosino ${ }^{5}$ or something like that then I can go, I will go, but every Sunday! It doesn't alter my religion and I would be a good person and still comply with all the things that l've learned, but I also need to have a balance in my familylife too so take the girls out, I'm not gunna have them at church on a Sunday morning because it's not gunna happen, half the day's gone... (Selena, 43 years, second-generation female)

It was not uncommon for participants whose partners were not of Greek-Cypriot descent to attend without them, and also to speak of the tensions and negotiations that occurred in respect of religious practices. For example, one couple were in disagreement about whether their son should be christened, with the English partner feeling worried about the ceremony and how her child would experience it. This illustrates how the increase in mixed ethnicity marriages and partnerships among later-generations contributed to intergenerational differences in the observance of religion.

Although individuals like Selina did not attend church regularly, they ensured that they went for cyclical events and life-cycle rituals, when particular importance is placed on the memorials of deceased loved ones, and Easter. They might be described as 'cultural Christians', not professing a faith but attending church at special occasions. As was discussed previously, these occasions were more often than not associated with GreekCypriot traditions:

I go once a year when it's my dad's memorial and this year ... I didn't stay. My mum makes all this stuff ${ }^{6}$, but I stayed for the service then I had to come away because we'd been invited to our friend's for lunch. Stamatis [brother] was there [at the service], I said (whispers) 'Stamatis, I'm gunna go' and he said, 'go now while the going's good' (laughs). My mum will probably give me a good telling off when I see her, but, whatever (laughs). (Anthea, 56 years, second-generation female)

\footnotetext{
4 The service would usually finish around 12pm, but most attendees would stay later for tea/coffee and cake and to chat.

${ }^{5}$ Cypriot for 'memorial'.

${ }^{6}$ It is a Greek Orthodox tradition that relatives of the deceased make bread and boiled wheat for the memorial service.
} 
The example reveals much about 'ethnic choice'. Anthea appears to attend the service out of a sense of duty and to please her mother. Yet, while she stayed for the service, she eschewed ethnic food and a private family gathering in favour of another meal with friends, although her brother chose to stay. This episode demonstrates that religious rituals and cultural practices retain some symbolic significance but are competing with secular, non-ethnic demands. Given the importance of sharing food in the Greek-Cypriot community, her decision not to stay marks a considerable departure from tradition; one that her brother chose not to take.

It also demonstrates that the physical space of the church is an important container for continued cultural practices. Whilst opting out of the private sharing of food, Anthea felt a need to attend the church service to fulfil her public obligations to her family and the wider ethnic community. Without the church setting, it is unclear whether these public life-cycle rituals would continue. As Goulbourne et al. (2010:102) suggest, attending such events provides individuals with the opportunity to celebrate ethnic social and cultural practices, and in doing so, reinforce 'their respective understandings of belonging and collective membership to their ethnic group'. This occurred in the study as participants engaged in shared rituals with the wider congregation and there was a sense of 'coming together' during these events, which reaffirmed social bonds and translocality.

In general, the second-generation had a flexible attitude toward church attendance and exerted 'ethnic choice' to 'dip in' and 'dip out' as they pleased. Nevertheless, the majority of the second-generation parents recognised that church and school reproduced their ethnic identity and, consequently, attempted to impress these ideas on their children by engaging them in these spaces. Many third-generation adults confirmed that the GreekCypriot Orthodox church had been significant in their youth but that it now held little meaning for them. Church and its rituals were resisted in part due to a lack of belief, reflecting the wider secularisation of society, but also because the ethnic identity seemed less important. Over time, the church and school did not fulfil the function of providing a 'home away from home' or of cultivating the same sense of belonging within the ethnic community as they did for members of the first-generation. Some of the older members of the third-generation were cynical about their experiences of church and often used humour when recounting them. For example, one interviewee confessed to not really wanting to attend Greek School at the time and it seemed to be a bit of a chore, hence he preferred to have a bit of a joke and not take it too seriously: 
We went to the Greek School on a Sunday morning and the Greek School just consisted of the just telling, sort of teaching you Greek nursery rhymes, the nursery rhymes had nothing to do with nursery and had everything to do with hatred towards the Turks [...] and the Greek teacher had a wig (laughing), we would always have a go, we'd always sort of wind her up about her wig because she didn't help the situation by having different coloured wigs [...] (Isaac, mid-thirties, third-generation male)

He went on to speak of his experience of having to be baptised by an Orthodox priest so that he could attend a local church-run school. The baptism only occurred for this reason and was devoid of all spiritual and ethnic significance for Isaac (although this was not the case for his parents and grandparents). A similar view was held by other interviewees who were obliged not only to attend, but actively participate in church services:

They [older family members] just dragged me there ... but you know, it's religion isn't it? When you get it thrown upon you, you just gotta deal with it? [...] But like l'd go down there and then like I would get a tap on the shoulder and there'd be some Greek guy there, like, 'come here' ... two seconds later I'm in, like, a robe and then, like, waving incense and stuff and I'm thinking like I'm not even that religious!' (Anthony, 27 years, third-generation male)

Here Anthony refers to a member of the church as 'some Greek guy', implying difference with his own identity. While members of the second-generation, such as Anthea above, were prepared to 'go along' with church and its rituals in an effort to assert ethnic identity, third-generation members like Anthony and Isaac used their ethnic choice to opt out of these practices when they became adults, illustrating the church as a translocal space was less important to them.

Younger members of the third-generation also lacked interest in the church. It was not uncommon for the children (as well as some of the adults) to find it difficult to follow the service, even those who had a good grasp of the Greek language. This was worsened by having to stand for long periods, as is the traditional custom during Orthodox services. While participation in such rituals enabled the first-generation to enact and experience collective affective belonging in a translocal space, this was not necessarily the case for the younger participants, who struggled to understand the spiritual and linguistic meanings of the service. 
Whereas religious services allowed ethnic identities of first-generation migrants to be asserted and performed, their unfamiliarity to later-generations served to highlight distinction and difference between the generations. Given the reluctance of second- and third-generation migrants to engage fully with church services, as noted above, this might suggest that translocal spaces based on religion may be in decline and other, more secular, spaces may become more important to new generations. An example of these are 'complementary schools' or 'language schools'.

\section{RE-EMERGING TRANSLOCAL SPACE}

The physical building of the church allowed the formation of other significant translocal spaces and practices to occur, especially the establishment of a Greek language school in the building. The school was well attended by young members of the community, aged from five years up to their late teens. Young people usually would attend one evening a week and also on a Saturday, with older students working towards achieving their Greek GCSE and/or A Level as they progressed. The significance of the school also went beyond its educative purpose for some of the more elderly members of the community:

School is important, and the community, because we belong somewhere, I believe. We have a community...we are not English, are we? (Anna, 81 years, firstgeneration female)

Complementary schools that teach language have become more numerous in the UK and have become part of the weekly routine for many younger people from ethnic minority backgrounds (Kelly, 2016). They also have the potential to be important translocal spaces by drawing together members of local ethnic communities and teaching them about (distant) national practices and identities.

Greek School was deemed more important than the church by most of the younger participants in our study; its perceived value was age dependent. Younger children enjoyed the school although this waned in their early teens, only to be re-invigorated by the challenge of exams in their later teens. This was summarised by one interviewee:

I used to really hate it, not because it was bad, but we had so many different teachers 'cus they like change every two years usually. So when I was younger I really hated it 'cus I just couldn't be bothered to go, I didn't see the point [...] then gradually as you get to like GCSE you like think you need to go to do well so... (Jasmine, 15 years, third-generation female) 
Jasmine's engagement with Greek School changed as she got older, demonstrating that age, as well as generation, is an important determinant of people's engagement with translocal space.

Thus, church and school helped to develop bonding capital between generations. Yet, there was also strong evidence that they also strengthened bridging capital by providing translocal space for other nationalities who practised Orthodox Christianity. Thus, the regular priest was a Greek-speaking Englishman rather than a Greek or Cypriot. Over the years, the service had also been adapted so that, rather than being conducted solely in Greek, some sections were also repeated in English. Although this meant a lengthy service, it reflected cultural changes among later-generations and allowed those who were not fluid in the Greek language, such as third generations, to participate

More significantly, the church's regular congregation has recently been bolstered by firstgeneration Romanian and Polish migrants who had travelled to Britain following EU accession. This is to such an extent that Romanian communicants have out-numbered Greek-Cypriots and a Romanian priest often celebrates the service. Another new language has been incorporated into the service, with some sections also being repeated in Romanian.

The multi-national nature of the church illustrates its wider relevance beyond the GreekCypriot community and illustrates its translocal significance for different enthnicities. As Goulbourne et al. (2010) assert, multi-ethnic churches are an important place where individuals can extend their friendship networks into other ethnic groups. This shows the importance of the church as both a religious and cultural site; the church is not only a religious space, it is also an important local space that transcends ethnic categories. The multi-ethnic nature of the church can also be linked to the intergenerational framework; the Romanians and Polish in attendance were mainly first-generation migrants (who often took their children). Once again, we see the importance of the church shortly after migration for first-generation migrants; this was the case for Greek-Cypriots in the 1950s and 1960s and continues to be so for Romanian and Polish migrants in the 2000s.

\section{CONCLUSION}


The idea of translocality has often used to understand the tension between 'mobility and locality' and, more specifically, how places are socially produced through assemblages of flows, movements and local practices (Greiner and Sakdapoldak 2013). By examining inter-generational change, we have demonstrated that time, as well as space, is a significant component in the production of translocal places. As the name suggests, translocal spaces have been viewed in relation to other localities, both near and far (Guarnizo and Smith, 1998), but our work suggests that it is important to consider how the cultural and material importance of translocal space changes over time.

These ideas have been exemplified using the example of the church. In broad terms, we support existing studies that have suggested that places of worship hold important value for migrant communities (Ehrkamp and Nagel, 2012). The church provided a space to draw together members of an ethnic minority, strengthening their community ties and offering a way of performing particular ideas of nationality and culture. In doing so, it provided social and cultural links to distant people and places through the performance of shared practices in England and Cyprus. The performance of Greek Orthodox beliefs pointed to the significance of mobilities-beyond-migration: most worshippers were not migrants themselves yet material, symbolic and cultural spaces of the church reflected a flow of ideas, spiritual practices, symbols and knowledge that transcended the immediate locality (Greiner and Sakdapoldak 2013). Yet, the meanings ascribed to the church and the practices of religion changed over time, which had two important consequences for its status as a translocal space.

First, there was a decline in religious practice over time that meant the significance of the church changed to the Greek-Cypriot diaspora. First-generation migrants were the strongest attenders and valued services for their national as well as spiritual value. Participation linked them to a wider communion of Greek Orthodox Christians in Cyrus. Some second-generation migrants were content to attend key services, many in the third-generation opted to abstain once they reached adulthood. While this partly reflects a national trend towards secularisation, when religion is so closely linked to national identity: a decision to stop practising also limits engagement with the Greek-Cypriot community. While teachings from church and family try to proscribe these, secular and societal pressures from outside the ethnic community challenge them. The exercise of ethnic choice becomes more significant to later-generations and challenges national forms of identity. While some studies have shown how participation in church rituals can be seen as one way of performing a 'real' or 'authentic' ethnic identity (Fortier, 1999), an 
intergenerational perspective demonstrates these views are mitigated over time by secular practices. The space of the church remained important but secular activities, such as the Greek School, rather than spiritual ones became more important to successive generations. It would also be instructive to examine how other, more secular spaces such as cafes or businesses, change their significance over time.

The significance of translocal space therefore changes over time. The range of intra- and inter-generational views means that these changes cannot be simply measured or quantified but, rather, need to be understood using process-based (Wessendorf, 2013), actor-orientated (Greiner and Sakdapoldak 2013). Our work recognise that translocal space is (re)created, contested and sometimes transgressed between generations. It is important to consider the significant of historical contingencies and how these change over time to understand the relational importance of translocal space. We suggest that studying intergenerational change and difference is an important way of doing this.

Second, the growing presence of Romanians points to the significance of the church as a transnational space of Orthodox Christianity rather than a container for Greek-Cypriot culture. The global, spiritual relevance of the church is affirmed by international migration but, at the same time, its local meaning is altered and modified. Although previous work has tended to consider translocal space from the perspective of one ethnic group, it is clear that more research is needed on the multi-ethnic, transnational appropriation of translocal space by different ethnic groups. This diversity emphasises the importance of transnational thinking in migration studies. This lends weight to Ho's (2008.1287) argument that immigration studies should move beyond examining the binaries of sending and receiving societies and, instead, consider how migrants experiences are interwoven with other migrants from other places, to produce truly translocal spaces.

To conclude, the idea of translocality reveals much about the importance of local spaces to migrants and, at the same time, trace how their lived experiences are shaped by morethan-migratory mobilities than extend beyond national boundaries. We argue that a stronger focus on change over time allows more nuanced understandings of the way in which places are socially produced in relation to wider networks and places (Greiner and Sakdapolrak (2013). We advocate intergenerational research as a way of achieving this.

\section{ACKNOWLEDGEMENTS}


This work has been carried out as part of a university-funded PhD. We are also deeply grateful to research participants for sharing their stories.

\section{REFERENCES}

Alba, R., Logan, J., Lutz, A. \& Stults, B. (2002). Only English by the third generation? Loss and preservation of the mother tongue among the grandchildren of contemporary immigrants. Demography, 39(3), 467-484.

Anthias, F. (1992). Ethnicity, Class, Gender, and Migration: Greek Cypriots in Britain. Avebury: Aldershot.

Appadurai, A. (1996). Modernity at Large: Cultural Dimensions of Globalization. Minneapolis and London: University of Minnesota Press.

Bell, V. (1999). Performativity and belonging: an introduction. Theory, Culture \& Society, 16(2), 1-10.

Brickell, K. \& Datta, A. (2011). Introduction: translocal geographies. In: Brickell, K. and Datta, A. (Ed.) Translocal Geographies: Spaces, Places, Connections (pp. 3-20). Farnham: Ashgate.

Burrell, K. (2005). Urban narratives: Italian and Greek-Cypriot representations of community in post-war Leicester. Urban History, 32(3), 481-499.

Charalambous, J., Hajifanis, G., \& Kilonis, L. (1988). The Cypriot Community of the UK: Issues of Identity. London: PNL Press.

Choudhry, S. (2010). Multifaceted Identity of Interethnic Young People: Chameleon Identities. Farnham: Ashgate

Christou, A. (2006). Deciphering diaspora - translating transnationalism: family dynamics, identity constructions and the legacy of 'home' in second-generation Greek-American return migration. Ethnic and Racial Studies, 29(6), 1040-1056.

Conradson, D. \& McKay, D. (2007). Translocal subjectivities: mobility, connection, emotion. Mobilities, 2(2), 167-174.

Constantinides, P. (1977). The Greek Cypriots: factors in the maintenance of ethnic identity. In Watson, J.L. (Ed). Between Two Cultures: Migrants and Minorities in Britain (pp 269-300). Oxford: Basil Blackwell.

Datta, A. (2011) Translocal geographies of London: belonging and 'otherness' among Polish migrants after 2004. In Brickell, K. and Datta, A. (Ed.) Translocal Geographies: Spaces, Places, Connections (pp. 73-92). Farnham: Ashgate. 
Dwyer, C. (1999). Contradictions of community: questions of identity for young British Muslim women. Environment and Planning A, 31(1), 53-68.

Dwyer, C. (2002). Where are you from? Young British Muslim women and the making of 'home'. In McEwan, C. and Blunt, A. (Ed). Postcolonial Geographies (pp 184-199). London: Continuum.

Dwyer, C., Tse, J. \& Ley, D. (2015). 'Highway to Heaven': the creation of a multicultural, religious landscape in suburban Richmond, British Columbia Social and Cultural Geography 17, 667-693

Ehrkamp, P and Nagel, C (2012). Immigration, places of worship and the politics of citizenship in the US South. Transactions of Institute of British Geographers $37,624-638$

Faist, T. (2000). Transnationalization in international migration: implications for the study of citizenship and culture. Ethnic and Racial Studies, 23(2), 189-222.

Ferbrache, F.E. \& Yarwood, R. (2015). Britons abroad or European citizens? The negotiation of (trans)national space and citizenship by British migrants in France. Geoforum, 62: 73-83.

Foner, N. \& Dreby, J. (2011). Relations between the generations in immigrant families. The Annual Review of Sociology, 37: 545-564.

Fortier, A. (1999). Re-membering places and the performance of belonging(s). Theory, Culture \& Society, 16(2), 41-64.

Fortier, A. (2006). Community, belonging and intimate ethnicity. Modern Italy, 11(1), 63-77.

Georgiou, M. (2001). Crossing the boundaries of the ethnic home: media consumption and ethnic identity construction in the public space: the case of the Cypriot Community Centre in North London. International Communication Gazette, 63(4), 311-329.

Glick Schiller, N. \& Caglar, A. (2009). Towards a comparative theory of locality in migration studies: migrant incorporation and city scale. Journal of Ethnic and Migration Studies, 35(2), 177-202.

Goulbourne, H., Reynolds, T., Solomos, J. \& Zontini, E. (2010). Transnational Families: Ethnicities, Identities and Social Capital. New York: Routledge.

Greiner, C. \& Sakdapolrak, P. (2013). Translocality: concepts, applications and emerging perspectives. Geography Compass, 7(5), 373-384. 
Guarnizo, L. (2000) 'Notes on transnational' Paper presented at the Conference on Transnational Migration: Comparative Theory and Research Perspectives, Oxford, England (June).

Guarnizo, L. E. and Smith, M. P. (1998). The locations of transnationalism. In: Smith M. P. and Guarnizo L. E. (eds) Transnationalism from below. New Brunswick, London. Transaction Publishers, pp. 3-34.

Hall, S. \& Datta, A. (2010) The translocal street: shop signs and local multi-culture along the Walworth Road, south London. City, Culture and Society, 1(2), 69-77.

Hammarstedt, M. (2009). Intergenerational mobility and the earnings position of first-, second-, and third-generation immigrants. Kyklos, 62(2), 275-292.

Hatfield, M.E. (2011). British families moving home: translocal geographies of return migration from Singapore. In Brickell, K. and Datta, A. (Ed.) Translocal Geographies: Spaces, Places, Connections (pp. 55-72). Farnham: Ashgate.

Ho, E. (2008). Citizenship, migration and transnationalism: a review and critical interventions. Geography Compass, 2, 1286-1300.

Ho, E.L., \& Hatfield, M.E. (2011). Migration and everyday matters: sociality and materiality. Population, Space and Place, 17(6), 707-713.

Hopkins, P.E. (2006). Youthful Muslim masculinities: gender and generational relations. Transactions of the Institute of British Geographers, 31(3), 337-352.

Josephides, S. (1988). Honour, family, and work: Greek Cypriot women before and after migration. In Westwood, S. and Bhachu, P. (Ed). Enterprising Women: Ethnicity, Economy and Gender Relations (pp 34-57). London: Routledge.

Kasinitz, P., Waters, M.C., Mollenkopf, J.H. \& Anil, M. (2006). Transnationalism and the children of immigrants in contemporary New York. In Levitt, P. and Waters, M.C. (Ed). The Changing Face of Home: The Transnational Lives of the Second Generation (pp 145-167). New York: Russell Sage Foundation.

Kelly, C. (2016). Saturday and back to school? Eastern European complementary schools in the UK. Retrieved July 10, 2017, from http://www.migrantyouth.org/resource/saturday-and-back-to-school-easterneuropean-complementary-schools-in-the-uk/

Kelly, P. \& Lusis, T. (2006). Migration and the transnational habitus: evidence from Canada and the Philippines. Environment and Planning A, 38(5), 831-847. 
Kim, B.W. \& Yoo, G.J. (2015). Adult children of Korean immigrants: maintaining language and negotiating ethnic identities through generations. KAERA Research Forum, 2(1), 28-40.

King, R., Christou, A., Goodson, I. \& Teerling, J. (2008). Tales of satisfaction and disillusionment: second-generation "return" migration to Greece and Cyprus' Diaspora. A Journal of Transnational Studies, 17(3), 262-287.

King, R., Christou, A. \& Teerling, J. (2011). 'We took a bath with the chickens': memories of childhood visits to the homeland by second-generation Greek and Greek Cypriot 'returnees'. Global Networks, 11(1), 1-23.

Knott, K. \& Khokher, S. (1993). Religious and ethnic identity among young Muslim women in Bradford. Journal of Ethnic and Migration Studies, 19(4), 593-610.

Kong, L. (1999). Globalisation and Singaporean transmigration: Re-imagining and negotiating national identity. Political Geography, 18(5), 563-589.

Kong, L. (2010). Global shifts, theoretical shifts: changing geographies of religion. Progress in Human Geography, 34(6), 755-776.

Leung, M. (2004). Chinese Migration in Germany: Making Home in Transnational Space. London: IKO.

Levitt, P. (2009). Roots and routes: understanding the lives of the second generation transnationally. Journal of Ethnic and Migration Studies, 35(7), 12251242.

Levitt, P. \& Waters, M.C. (2006). The Changing Face of Home: The Transnational Lives of the Second Generation. New York: Russell Sage Foundation.

Ley D. (2008). The immigrant church as an urban service hub. Urban Studies, 45: 2057-2074.

Lieblich, A., Rivka, T. \& Tamar, Z. (1998). Narrative Research: Reading, Analysis and Interpretation. Thousand Oaks, California: Sage.

Oakes, T. \& Schein, L. (2006). Translocal China: Linkages, Identities and the Reimagining of Space. Oxon: Routledge.

Papapavlou, A. \& Pavlou, P. (2001). The interplay of language use and language maintenance and the cultural identity of Greek Cypriots in the UK. International Journal of Applies Linguistics, 11(1), 92-113.

Parreñas, R. (2005). Long distance intimacy: class, gender and intergenerational relations between mothers and children in Filipino transnational families. Global Networks, 5(4), 317-336. 
Phillips, D. \& Robinson, D. (2015). Reflections on migration, community, and place. Population, Space and Place, 21(5), 409-420.

Portes, A. \& Rumbaut, R.G. (2001). Legacies: The Story of the Immigrant Second Generation. London: University of California Press.

Skrbiš, Z., Baldassar, L. \& Poynting, S. (2007). Introduction - negotiating belonging: migration and generations. Journal of Intercultural Studies, 28(3), 261269.

Smith, M.P. (2001). Transnational Urbanism: Locating Globalization. Malden: Blackwell.

Sullivan, T. (2012). 'I want to be all I can Irish': the role of performance and performativity in the construction of ethnicity. Social \& Cultural Geography, 13(5), 429-443.

Taylor, C. (2007). A Secular Age. Cambridge, MA: Belnap.

Teerling, J. (2011). The development of new 'third-cultural spaces of belonging': British-born Cypriot 'return' migrants in Cyprus. Journal of Ethnic and Migration Studies, 37(7), 1079-1099.

Tse, J.K.H. (2011) Making a Cantonese-Christian Family: Quotidian Habits of Language and Background in a Transnational Hongkonger Church. Population, Space and Place, 17(6), 756-768.

Waters, M.C. (1990). Ethnic Options: Choosing Identities in America. Oxford: University of California Press.

Wessendorf, S. (2013). Second-Generation Transnationalism and Roots Migration: Cross-Border Lives. Farnham: Ashgate.

Yang, D. (2011). Migrant remittances. The Journal of Economic Perspectives, 25(3), 129-151.

Zhou, M. (2009). Conflict, coping and reconciliation: intergenerational relations in Chinese immigrant families. In Foner, N. (Ed). Across Generations: Immigrant Families in America (pp 21-47). New York: N. Y. University Press. 


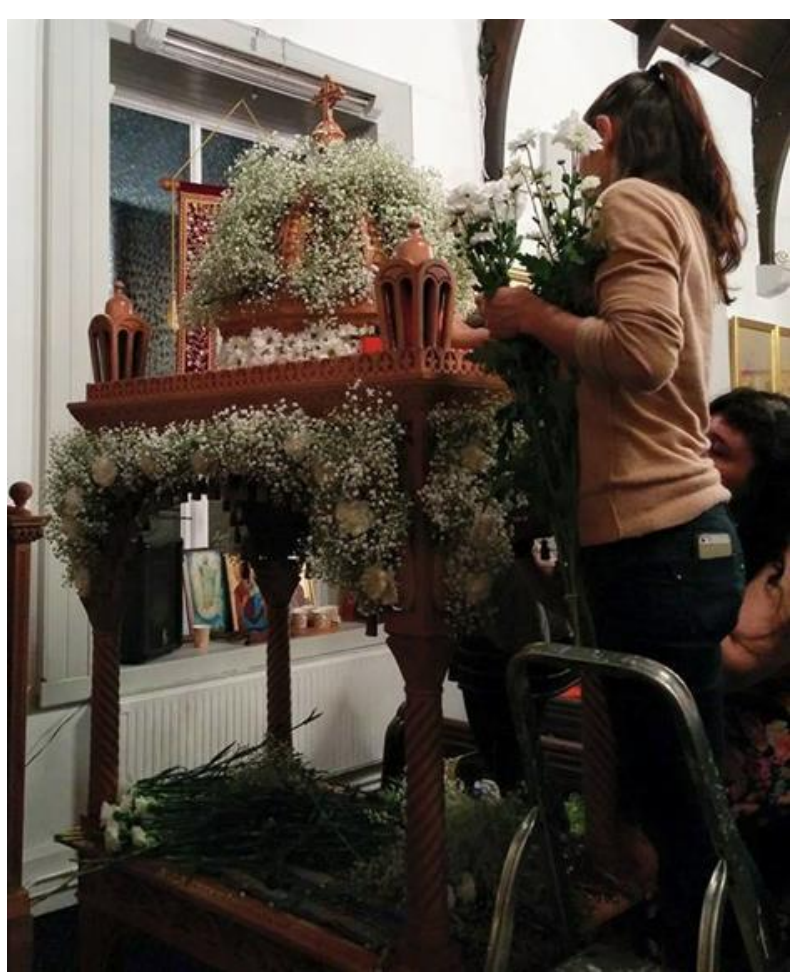

Figure 1 
Figure 2

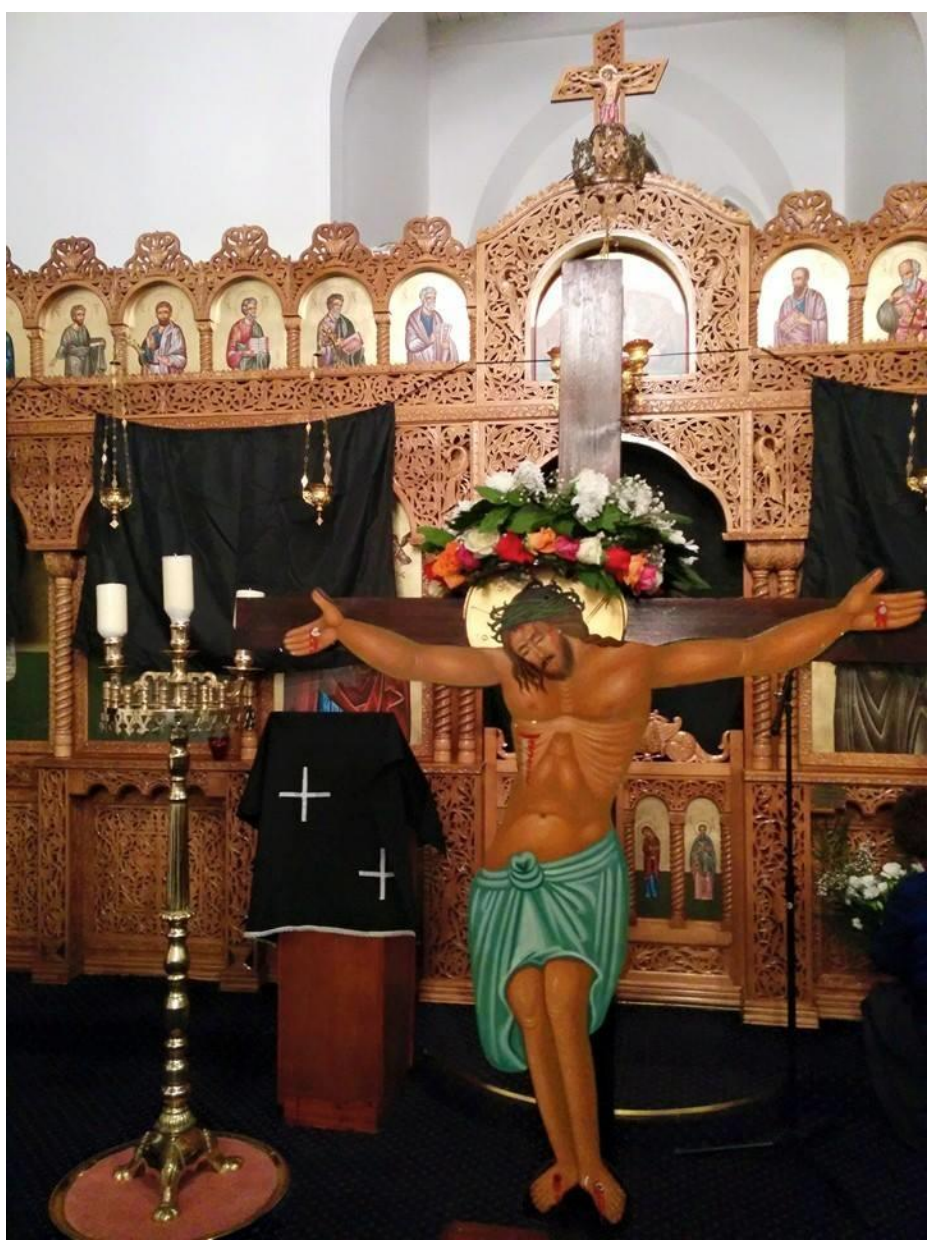

